firmed at two stages of the experiment, namely, on the twenty-eighth and fifty-fifth days. Investigations made on the fifty-fifth and seventy-sixth days on the renal cortical region suggested some disorder of the intrarenal circulation. Over a period of four months the systolic blood pressure did not rise significantly above the level in the pretreated period. The authors suggest that the lesions may have been eaused by impulses generated in the afferent nerve, following repeated chemical stimulation on the skin, passing through a reflex arc involving the higher central nervous system. These continue to the intraronal arteries by way of the sympathetic nerve, and the resulting ischæmia in the renal cortex may be the cause of the degeneration of the renal parenchymal cells, especially those of proximal convoluted tubules. The functional changes of the kidney are slight in the period before the lesions advance but they are readily perceived by histological examination.

\section{An Inventory of Abstracting Services}

THE Fédération Internationale de Documentation, 7 Hofweg, The Hague, Netherlands, is preparing, with financial assistance from the National Science Foundation in Washington, D.C., a comprehensive inventory of abstracting services covering the fields of science, technology and social sciences. It is expected that the study will take two years. The data will be collected by means of a questionnaire to be distributed at the beginning of February 1962. Besides gaining information about the nature and scope of each abstracting service, the questionnaire will also determine the number of periodica's consulted during the year, the existence of a reproduction service and whether translations can be obtained. On completion of this project, the Fédération plans to establish an international information centre, the first object being to give supplementary information on data revealed by the questionnaire. It is hoped that all abstracting services will co-operate in the scheme.

\section{Wellcome Senior Research Fellowships in Clinical Science}

To encourage medically qualified workers of exceptional ability to embark on careers of elinical research within the United Kingdom, the Wellcome Trustees are prepared to award one or two Wellcome Senior Research Fellowships in this field in 1962. The professors in charge of university departments of medicine, surgery and obstetrics in the United Kingdom are invited to put forward confidential nominations for these awards. Direct personal applications by candidates for these Fellowships will not be considered. The Fellowships will be awarded for one year in the first instance and will be renewable over four more years. It will be a condition of the appointment that the Fellow should be granted the status and responsibilities of a lecturer in the university department in which he is employed. On the assumption that the age of the Fellow at appointment will be about thirty, the stipend offered over the five-year period will be $£ 1,900$ a year, rising by increments of

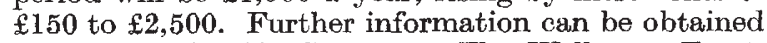
from the Scientific Secretary, The Wellcome Trust, 52 Queen Anne Street, London, W.I.

\section{Christmas Lectures for Young People}

Among the lectures organized for young people during Christmas and the following weeks are: The one hundred and thirty-second course of Christmas lectures at the Royal Institution, to be delivered by Sir Lawrence Bragg on "Electricity", including "What is Electricity?" (December 28), "How Electricity Travels" (December 30), "Motors and Dynamos" (January 2), "Electrical Oscillations and Electromagnetic Waves" (January 4), "Our Electrical Supply" (January 6), and "Conveying Information by Electricity" (January 9). Further information can be obtained from the Royal Institution, 21 Albemarle Street, London, W.1. Five children's Christmas holiday lectures on "The Painter, the Anatomist and the Surgeon" (Mr. H. Thompson, January 1), "Science in Crime Detection" (Dr. K. Simpson, January 2), "Family Life in Russia To-day" (Dr. J. Hunt, January 3), "The Romance of Huntington's Chorea" (Dr. Macdonald Critchley, January 4) and "How and Why We Hear" (Mr. T. Cawthorne, January 5) at the Royal Society of Medicine at 2.30 p.m. Further information can be obtained from the Assistant Secretary, Royal Society of Medicine, 1 Wimpole Street, London, W.I. A young people's lecture, to be delivered by Prof. M. Stacey on "Nature's Plastics" at the Plastics Institute on January 5, at 2.30 p.m. Further information can be obtained from the Plastics Institute, 6 Mandeville Place, London, W.I.

\section{Announcements}

Prof. N. R. Dhar, recently head of the Chemistry Department and director of the Sheila Dhar Institute of Soil Science, University of Allahabad, has been elected as a corresponding member of the Paris Academy of Sciences in the Chemistry Section.

Mr. P. S. Brigas, of T. N. and F. H. Briggs (Tanners), Ltd., Leicester, has been appointed chairman of the Council of the British Leather Manufacturers' Research Association in succession to $\mathrm{Mr}$. E. A. Hutchings, who has left the leather industry.

Dr. Olivier Hrroux has bcen appointed scientist. in-residence at the U.S. Naval Radiological Defense Laboratory, San Francisco, California. This is the first appointment under a new programme at the Laboratory for visiting distinguishod scientists from other scientific communities. Dr. Heroux is a member of the Canadian National Research Council and will be at the Laboratory during leavo of absence of one year from his post in Canada.

THe annual meeting of the American Mathematical Society will be held at the Sheraton-Gibson Hotel, Cincinnati, during January 22-25. Further information can be obtained from J. W. T. Youngs, American Mathematical Society, Bloomington, Indiana.

ERratum. Dr. G. B. Robertison writes: In "Crystal and Molecular Structure of Diphenyl" (Nature, $191,593 ; 1961)$ the value of the constant in the asymmetric-unit plane equation was reported incorrectly due to a computational error. The correct value of this constant is 0.00864 , the equation of the plane is:

$$
-0.30584 X+0.55575 Y+0.77305 Z^{\prime}=0.00864
$$

and the perpendicular separation between the ring planes is $\sim 0.017 \AA$. (not $\sim 0.2 \AA$.). This separation is not statistically significant and the two rings are, therefore, coplanar within the limits of the experimental error. 